\title{
Anti-obesity potential of selected tropical plants via pancreatic lipase inhibition
}

\begin{abstract}
Natural products are a vast source of potential compounds that can be developed as antiobesity agent. One of the mechanisms of anti-obesity agents is inhibition of pancreatic lipase. Assay of 24 crude extracts for their in vitro activity against porcine pancreatic lipase (PPL) detected four extracts demonstrating high $(>70 \%)$ inhibition, seven extracts had medium (30-70\%) inhibition and the remaining 13 extracts exhibited low $(<30 \%)$ inhibition when incubated with PPL at a concentration of $500 \mu \mathrm{g} / \mathrm{ml}$ for $10 \mathrm{~min}$ at $37^{\circ} \mathrm{C}$. Phyllanthus niruri extract displayed the most potent PPL inhibitor, followed by Orthosiphon stamineus, Murraya paniculata and Averrhoa bilimbi with the IC50 value of $27.7<34.7<41.5<55.2 \mu \mathrm{g} /$ $\mathrm{ml}$, respectively. P. niruri \& $O$. stamineus (the best two extracts) showed noncompetitive and uncompetitive inhibition, respectively. P. niruri \& O. stamineus displayed total phenolic content of $431.0 \pm 0.01$ and $103.0 \pm 0.01 \mathrm{mg} \mathrm{GAE} / \mathrm{g}$ dry extract, while total flavonoid content of $14.8 \pm 0.07$ and $21.6 \pm 0.03 \mathrm{mg} \mathrm{QE} / \mathrm{g}$ dry extract, respectively. Both $P$. niruri \& $O$. stamineus extracts showed high antioxidant activity, with EC50 values of 8.4 and $26.3 \mu \mathrm{g} /$ $\mathrm{ml}$, respectively. The results suggest that $P$. niruri \& $O$. stamineus may be beneficial for obesity treatment via pancreatic lipase inhibition action.
\end{abstract}

Volume 6 Issue 4 - 2017

\author{
Norsyuhada Alias, ${ }^{1,2}$ Thean Chor Leow, ${ }^{2}$ \\ Mohd Shukuri Mohamad Ali, ${ }^{2}$ Asilah Ahmad \\ Tajudin, ${ }^{2}$ Abu Bakar Salleh, ${ }^{2}$ Raja Noor Zaliha \\ Raja Abd Rahman ${ }^{2}$ \\ 'Department of Biomedical Sciences, International Islamic \\ University Malaysia, Malaysia \\ ${ }^{2}$ Universiti Putra Malaysia, Malaysia
}

Correspondence: Raja Noor Zaliha Raja Abd Rahman, Enzyme and Microbial Technology Research Centre, Universiti Putra Malaysia, 43400 UPM Serdang, Selangor, Malaysia, Email rnzaliha@upm.edu.my

Received: March 07, 2017 | Published: April 06, 2017

Keywords: pancreatic lipase inhibitor, phyllanthus niruri, orthosiphon stamineus, obesity

\section{Introduction}

Pancreatic lipase inhibition is one of the approaches used to determine the potential efficacy of natural products as an anti-obesity agent. The mechanism involves inhibition of dietary triglyceride absorption, as this is the main source of excess calories. The success of orlistat as the only lipase inhibitor marketed with regulatory approval has prompted research for alternative lipase inhibitors with lesser side effects than orlistat. Up to now, many extracts and pure compounds have been identified and reported to exhibit considerable in vitro inhibitory activity against pancreatic lipase. Lipase inhibitors have been detected in different plant species, including Ligustrum purpurascens $;{ }^{1}$ Eisenia bicyclis $;{ }^{2}$ Nageia wallichiana $;{ }^{3}$ Panax japonicas; ${ }^{4}$ Salacia reticulate $;{ }^{5}$ Acanthopanax senticosus ${ }^{6}$ \& Nelumbo nucifera. ${ }^{7}$ Sharma et al., ${ }^{8}$ reported that 75 medicinal plants belong to different families in Korea were screened for their anti-lipase activity, using a radioactive method. According to their report, methanolic extracts of three plants namely, Eriochloa villosa (Thunb.) Kunth, Orixa japonica Thunb., and Setaria italica (L.) Palib. exhibited strong in vitro anti-lipase activity with more than $80 \%$ inhibition. In China, the methanolic extracts of 37 traditional Chinese herbal medicines of different families were assayed for their in vitro activity against porcine pancreatic lipase (PPL) by using spectrophotometry with 2, 4-dinitrophenyl butyrate as a synthetic substrate. Extracts from two herbs, Prunella vulgaris L. (Labiatae) and Rheum palmatum L. (Polygonaceae), at a concentration of $200 \mu \mathrm{g} /$ $\mathrm{ml}$, significantly inhibited PPL by $74.7 \%$ and $53.8 \%$, respectively. ${ }^{9}$ Recently, Dechakhamphu \& Wongchum ${ }^{10}$ screened the effect of 28 medicinal plants on inhibition of pancreatic lipase and evaluate the phytochemical contents of the extracts. Their finding revealed that extracts from four herbs, Memecylon edule Roxb., Garcinia vilersiana Pierre, Cryptolepis elegans Wall., and Phyllanthus chamaepeuce Ridl. Strongly inhibited PPL at a concentration of $100 \mu \mathrm{g} / \mathrm{ml}$, by $90.97 \%$, $92.04 \%, 94.64 \%$ and $95.38 \%$, respectively. The authors also stated that there was a significant positive correlation between phenolic, flavonoid, and alkaloid contents with inhibition activity.

Obesity is recognized as a risk factor in the metabolic disorders development, hyperlipidemia, atherosclerosis, diabetes mellitus, hypertension, cancer and cardiovascular disease. ${ }^{11}$ Pancreatic lipase inhibition is classified as one of the approaches to treat obesity due to the facts that $50-70 \%$ total dietary fat hydrolysis were performed by pancreatic lipase. ${ }^{12}$ Besides, pancreatic lipase inhibition does not alter any central mechanism; make it an ideal approach for obesity treatment. ${ }^{13}$ According to the World Health Organization (WHO), medicinal plants contribute significantly to primary health care. More recently, WHO presented a Traditional Medicine Strategy for 2014-2023. ${ }^{14}$ According to their report, the output of Chinese materia medica was estimated about US\$83.1billion in 2012, an increase of more than $20 \%$ from the previous year. In the Republic of Korea, annual expenditures on traditional medicine reached US\$4.4billion in 2004, rising to US\$7.4billion in 2009, while out-of-pocket spending for natural products in the United States was US\$14.8billion in 2008. With more people avoiding chemical drugs due to the fear of side effects, preference is now towards natural-based products, thus justifying extensive research in this field. Accordingly, the aim of this study is to examine the pancreatic lipase-inhibitory potential of 24 methanolic extracts from different parts (leaves, fruits, rhizomes, shoot and whole plant) of selected plants found in tropical countries.

\section{Materials and methods}

\section{Materials}

The plants of interest, plant parts list and source of plants are shown in Table 1. The selection of plants was based on the literature surveys of the scientific evidence and personal interview with local herbalist on the usage of selected plants for slimming treatment. The PPL (Type II) (EC 3.1.1.3), p-nitrophenyl butyrate (pNPB) and orlistat were purchased from Sigma-Aldrich (St Louis, MO, USA). All other chemicals and solvents were of analytical grade. 
Table I List of plants selected for lipase inhibition screening

\begin{tabular}{|c|c|c|c|c|}
\hline No. & Scientific name & English name & Parts tested & Source \\
\hline I & Alpinia galangal & Galanga Root & Rhizomes & TPU, UPM \\
\hline 2 & Andrographis paniculata & King of Bitter/Creat/Bile Earth & Leaves & TPU, UPM \\
\hline 3 & Averrhoa bilimbi & Cucumber Tree/Tree Sorrel & Leaves & TPU, UPM \\
\hline 4 & Carica papaya & Papaya & Leaves & TPU, UPM \\
\hline 5 & Curcuma aeruginosa Roxb. & Nil & Rhizomes & TPU, UPM \\
\hline 6 & Cymbopogon nardus & Citronella & Leaves & TPU, UPM \\
\hline 7 & Cymbopogon nardus & Citronella & Shoots & TPU, UPM \\
\hline 8 & Garcinia atroviridis & Nil & Fruits & Wet market, Sri Serdang \\
\hline 9 & Garcinia atroviridis & Nil & Leaves & TPU, UPM \\
\hline 10 & Gynura procumbens (green) & Mollucan Spinach (green) & Leaves & TPU, UPM \\
\hline II & Gynura procumbens (red) & Mollucan Spinach (red) & Leaves & TPU, UPM \\
\hline 12 & Hibiscus sabdariffa & Roselle & Fruits & Wet market, Sri Serdang \\
\hline 13 & Kaempferia galangal & Fingeroot & Leaves & TPU, UPM \\
\hline 14 & Momordica charantia & Bitter Gourd & Fruits & Wet market, Sri Serdang \\
\hline 15 & Morinda citrifolia & Noni & Leaves & TPU, UPM \\
\hline 16 & Murraya paniculata & Orange Jessamine & Leaves & TPU, UPM \\
\hline 17 & Orthosiphon stamineus Benth & Cat Whiskers & Leaves & TPU, UPM;AgriPearl Sdn. Bhd. \\
\hline 18 & Phaleria macrocarpa & God's Crown & Leaves & TPU, UPM \\
\hline 19 & Phyllanthus acidus & Malay Gooseberry & Leaves & TPU, UPM \\
\hline 20 & Phyllanthus niruri & Stone Breaker & Whole plant & TPU, UPM;AgriPearl Sdn. Bhd. \\
\hline 21 & Piper betle $L$. & Betel & Leaves & TPU, UPM \\
\hline 22 & Syzygium polyanthum & Bay & Leaves & TPU, UPM \\
\hline 23 & Tamarindus indica & Tamarind & Leaves & TPU, UPM \\
\hline 24 & Zingiber cassumunar & Cassumunar Ginger & Leaves & TPU, UPM \\
\hline
\end{tabular}

NIL, not having a common English name

TPU, UPM, taman pertanian university putra Malaysia

\section{Methods}

Method outline: Twenty-four crude extracts prepared using smallscale extraction was subjected to lipase inhibition assay screening. Four crude extracts exhibited more than $70 \%$ inhibition towards pancreatic lipase underwent IC50 and inhibition mode determination. Two crude extracts with the best IC50 value namely $P$. niruri \& $O$. stamineus were chosen for further analysis. Large-scale extraction was performed followed by lipase inhibition assay, antioxidant assay and phytochemical analysis of both extracts.

Plant extractions: All plant materials (leaves, shoots, rhizomes, whole plant and fruits) were washed thoroughly with clean water. Fruits, rhizomes, and shoots were cut into small pieces, then, all plant materials were air-dried in the shade at $25-30^{\circ} \mathrm{C}$. The dried plant materials were ground into fine powder using a lab-scale blender (Waring, USA). Fifty grams of the powdered materials were soaked in $500 \mathrm{ml}$ of $80 \%(\mathrm{v} / \mathrm{v})$ methanol and incubated for three days at ambient temperature $\left(25^{\circ} \mathrm{C}\right)$. The extracts were filtered using $150 \mathrm{mM}$ Whatman No. 1 filter paper and evaporated at $45^{\circ} \mathrm{C}$ in a rotary vacuum evaporator (Eyela, Japan). The dried crude extracts were then weighted and kept at $-20^{\circ} \mathrm{C}$ for further investigation. In order to protect the extracts from light, the bottles containing extracts were covered with aluminium foil.

\section{Lipase inhibition assay}

Lipase preparation: The crude PPL was dissolved in $50 \mathrm{mM}$ phosphate buffer $\mathrm{pH} 7(1 \mathrm{mg} / \mathrm{ml})$ and centrifuged at $12000 \mathrm{x}$ g for 5 min to remove all insoluble. ${ }^{15,16}$ Enzyme stock concentration was set at approximately $0.1 \mathrm{mg} / \mathrm{ml}$ for every $1 \mathrm{mg}$ solid PPL powder dissolved in $1 \mathrm{ml}$ of buffer.

Lipase inhibition reaction: The ability of the compounds to inhibit PPL was measured using the modified method previously reported by Lewis. ${ }^{16}$ The lipase activity was determined by measuring the hydrolysis of pNPB to p-nitrophenol at $405 \mathrm{~nm}$ using UV-transparent 96-well plates on an ELISA reader (BIO-TEK, Synergy HT, USA) Lipase assays were performed by incubating the plant extracts (final concentration of $500 \mu \mathrm{g} / \mathrm{ml}$ ) with PPL and pNPB in reaction buffer (50mM potassium phosphate buffer, $\mathrm{pH} 7.2,0.5 \%$ Triton X-100) 
for $10 \mathrm{~min}$. pNPB was first solubilized with $1 \%$ dimethylsulfoxide (DMSO) of the final volume, then diluted with the reaction buffer for a final concentration of $2.5 \mathrm{mM}$ in a $100 \mu 1$ reaction.

All assays were run at $37^{\circ} \mathrm{C}$ and reported results were the average of three replicates that were blank subtracted. Orlistat was used as a positive control. DMSO was used as a negative control and the activity was also examined with and without the inhibitor. One unit of activity was defined as the rate of reaction that produces $1 \mu \mathrm{mol}$ of p-nitrophenol permin at $37^{\circ} \mathrm{C}$. Inhibition of the lipase activity was expressed as the percentage decrease in the activity when PPL was incubated with the test compounds. Lipase inhibition (\%) was calculated according to the following formula:

$$
\text { Lipase inhibition }(I \%)=100-[(B-b) /(A-a) \times 100]
$$

Where A is the activity without inhibitor, a is the negative control without inhibitor, $\mathrm{B}$ is the activity with inhibitor and $\mathrm{b}$ is the negative control with inhibitor.

IC $_{50}$ determination: The concentration of four most active plant extracts giving 50\% lipase inhibition $\left(\mathrm{IC}_{50}\right)$ was performed using several concentrations of extracts, ranging from 0.1 to $0.6 \mathrm{mg} / \mathrm{ml}$. The $\mathrm{IC}_{50}$ value was calculated from the least squares regression line of the semi-logarithmic plot against percentage inhibition curves using GraphPad Prism Version 4.0 software (GraphPad Software Inc., San Diego, USA).

Inhibition mode determination: Four crude extracts exhibited more than $70 \%$ inhibition towards pancreatic lipase from screening analysis and were subjected to kinetic study in order to determine the inhibition mode. The inhibition mode was determined by Hanes-Woolf plot analysis resulting from the enzyme assay data containing increasing concentrations of $\mathrm{pNPB}(0.25,0.5,1.0,2.0,4.0$ and $6.0 \mathrm{mM})$ with the absence and presence of different concentration of extracts (10 and $50 \mu \mathrm{g} / \mathrm{ml}$ ) according to the Michaelis-Menten kinetics. The HanesWoolf plots were designed using the GraphPad Prism Version 4.0 software (GraphPad Software Inc., San Diego, USA).

DPPH radical scavenging activity assay: Antioxidant reducing activity on 2, 2-diphenyl-1-picrylhydrazil (DPPH) was carried out according to the method of Zakaria et al., ${ }^{17}$ with slight modification. DPPH free radical was dissolved in methanol for the preparation of stock solution with final concentration of $120 \mu \mathrm{M}$ in reaction mixtures. $O$. stamineus and $P$. niruri extracts were prepared using methanol. Ascorbic acid (Sigma - Aldrich, USA) was used as positive control. All samples and ascorbic acid were weighted accordingly to obtain stock solution samples with initial concentration of $1000 \mu \mathrm{g} / \mathrm{ml}$. The percentages of the scavenging activity at this initial concentration were compared. Serial dilution was then conducted in order to obtain several different concentrations. Final concentrations that were used for the test were $500 \mu \mathrm{g} / \mathrm{ml}, 250 \mu \mathrm{g} / \mathrm{ml}, 125 \mu \mathrm{g} / \mathrm{ml}, 62.50 \mu \mathrm{g} / \mathrm{ml}$, $31.25 \mu \mathrm{g} / \mathrm{ml}, 15.63 \mu \mathrm{g} / \mathrm{ml}$, and $7.81 \mu \mathrm{g} / \mathrm{ml}$.

Fifty microliter of DPPH solution was added to $100 \mu$ l of sample solutions in 96-well plate. The plate was then wrapped with aluminum foil to avoid exposure to light. The decrease in absorbance was determined at $515 \mathrm{~nm}$ using a microplate reader (BIO-TEK, Synergy HT, U.S.A.) after $30 \mathrm{~min}$ of incubation period at room temperature $\left(28^{\circ} \mathrm{C}\right)$. The test of each sample and ascorbic acid were conducted in triplicate. Mean, standard deviation and median effective concentration (EC50) of the results obtained were determined using GraphPad Prism software (GraphPad, USA). The percentage of inhibition was calculated using the following formula:

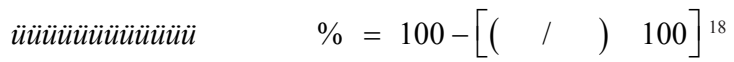

Where, $\mathrm{AS}=\mathrm{Absorbance}$ of sample; $\mathrm{AC}=\mathrm{Absorbance}$ of negative control (Methanol without sample)

\section{Phytochemical analysis}

Phytochemical analysis of $O$. stamineus and $P$. niruri extracts was carried out to quantify the total phenolic and flavonoid contents of both crude extracts.

Estimation of total phenolic content: This experiment was performed to determine the total phenolic content (TPC) according to the method described by Hakiman ${ }^{19}$ with slight modification. FolinCiocalteu phenol reagent (Sigma Chemical Co., USA) was diluted with distilled water at ratio $1: 1$. The diluted and fresh prepared Folin-Ciocalteu reagent $(20 \mu 1)$ was then added to $10 \mu 1$ of extracts in methanol $(1 \mathrm{mg} / \mathrm{ml})$. Distilled water $(80 \mu \mathrm{l})$ was added to the reactions. After $3 \mathrm{~min}, 40 \mu \mathrm{l}$ of $17 \%$ sodium bicarbonate (w/v) was added to the mixtures. The experiment was performed in a 96-well plate which was covered with aluminum foil. The plate was incubated and agitated at room temperature $\left(\sim 25^{\circ} \mathrm{C}\right)$ in the dark for $90 \mathrm{~min}$. Absorbance of samples was monitored at $760 \mathrm{~nm}$ using a microplate reader (BIOTEK, Synergy HT, USA) with distilled water served as a blank. All samples were tested in triplicate. Meanwhile, a standard curve with different concentration of gallic acid (Sigma Chemical Co., USA) $(0.2,0.4,0.6,0.8$, and $1 \mathrm{mg} / \mathrm{ml})$ was constructed using GraphPad Prism software (San Diego, CA). The phenolic content of extracts were interpolated from the gallic acid standard curve and expressed as gallic acid equivalent per gram of dry extract (mg GAE/g dry extract).

Estimation of total flavonoid content: Total flavonoid content (TFC) was measured by the modified method of aluminum chloride $\left(\mathrm{AlCl}_{3}\right)$ colourimetric assay. ${ }^{20,21} \mathrm{An}$ aliquot of extracts $(0.3 \mathrm{ml}, 1000 \mu \mathrm{g} /$ $\mathrm{ml}$ ) was added to a $10 \mathrm{ml}$ test tube containing $3.4 \mathrm{ml}$ of $30 \%$ methanol, $0.15 \mathrm{ml}$ of sodium nitrite $\left[\mathrm{NaNO}_{2}, 5 \%(\mathrm{w} / \mathrm{v})\right]$, and $0.15 \mathrm{ml}$ of $\mathrm{AlCl}_{3}$ $[10 \%(\mathrm{w} / \mathrm{v})]$. After $5 \mathrm{~min}, 1 \mathrm{ml}$ of $1 \mathrm{M}$ sodium hydroxide $(\mathrm{NaOH})$ was added. The solution was mixed and the absorbance was measured immediately against the reagent blank at $510 \mathrm{~nm}$ using a microplate reader (BIO-TEK, Synergy HT, USA). All samples were tested in triplicate. A standard curve with varying concentrations of quercetin $(20,40,60,80$, and $100 \mu \mathrm{g} / \mathrm{ml})$ was constructed using Graph Pad Prism software (San Diego, CA). The flavonoid content of extracts was interpolated from the quercetin standard curve and expressed as quercetin equivalent per gram of dry extract ( $\mathrm{mg} \mathrm{QE} / \mathrm{g}$ dry extract).

\section{Results and discussion}

\section{Lipase-inhibition of crude plant extracts}

There are many techniques that can be applied to assay lipase activity either by using natural or artificial triglyceride as the substrate. These techniques include spectrophotometric, turbidimetric, titrimetric, chromogenic and immunochemical detection..$^{22}$ In this study, pancreatic lipase inhibition assay of several selected plants was successfully conducted using the spectroscopic method with pNPB as the substrate. The assay was performed using 96-well plate and was read by microplate reader. This strategy was applied to facilitate the screening step, increase robustness, and maintain reproducibility of the assay. In this study, PPL was used as a model enzyme due to its properties, which is mostly equivalent to the human pancreatic lipase (HPL) with similar enzyme kinetics and behavior. ${ }^{12,23,24}$ Also, commercial crude PPL was available in bulk at a lower price. 
The preliminary PPL inhibition assay screening detected four extracts exhibiting high $(>70 \%)$ inhibition while seven extracts with medium (30-70\%) inhibition and the remaining 13 plant extracts showed either low $(<30 \%)$ or no inhibition when incubated with PPL at a final concentration of $500 \mu \mathrm{g} / \mathrm{ml}$ for $10 \mathrm{~min}$ at $37^{\circ} \mathrm{C}$. All plant extracts was set at $500 \mu \mathrm{g} / \mathrm{ml}$ as such concentration could give a consistent results with low standard deviation in the assay. Figure 1 shows the graph of the PPL inhibition assay screening result of all extracts. The four crude extracts with high inhibition towards pancreatic lipase are $O$. stamineus, $P$. niruri, M. paniculata and A. bilimbi, abbreviated as MK, DA, K and BB, respectively. All four plants with high inhibition were derived from their leaves extracts except for $P$. niruri which was prepared using the whole plant.

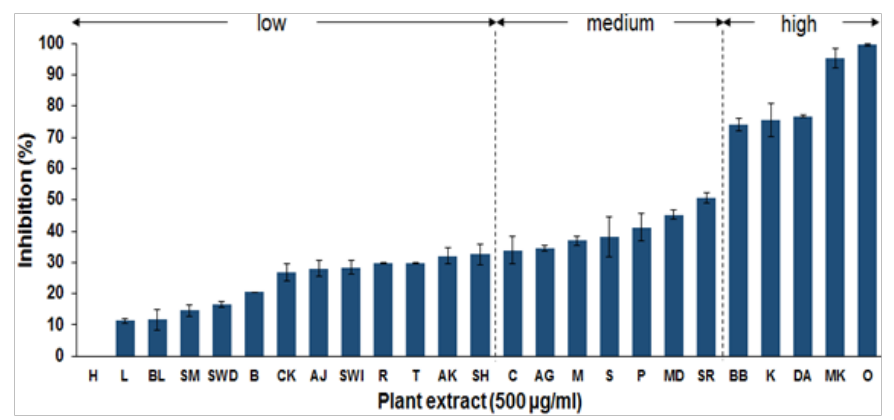

Figure I Screening of lipase-inhibitory activity from 24 methanolic extracts.

Plant extracts were divided into three categories, which were, low $(<30 \%)$ or no inhibition, medium $(30-70 \%)$ inhibition and high $(>70 \%)$ inhibition when incubated with PPL at a final concentration of $500 \mu \mathrm{g} / \mathrm{ml}$ for $10 \mathrm{~min}$ at $37^{\circ} \mathrm{C}$. Values were mean \pm standard deviation $(n=3)$. Sequence of plants from left to right (ascending order): $\mathrm{H}=A$. paniculata (leaves), $\mathrm{L}=A$. galangal (rhizomes), $\mathrm{BL}=Z$. cassumunar (leaves), $\mathrm{SM}=G$. procumbens (red) (leaves), $\mathrm{SWD}=C$. nardus (leaves), $\mathrm{B}=C$. papaya (leaves), $\mathrm{CK}=K$. galangal (leaves), $\mathrm{AJ}=T$. indica (leaves), $\mathrm{SWI}=C$. nardus (shoots), $\mathrm{R}=H$. sabdariffa (fruits), $\mathrm{T}=C$. aeruginosa Roxb. (rhizomes), $\mathrm{AK}=G$. atroviridis (fruits), $\mathrm{SH}=G$. procumbens (green) (leaves), $\mathrm{C}=P$. acidus (leaves), $\mathrm{AG}=G$. atroviridis (leaves), $\mathrm{M}=M$. citrifolia (leaves), $\mathrm{S}=S$. polyanthum (leaves), $\mathrm{P}=M$. charantia (fruits), $\mathrm{MD}=P$. macrocarpa (leaves), $\mathrm{SR}=P$. betle $\mathrm{L}$. (leaves). $\mathrm{BB}=A$. bilimbi (leaves), $\mathrm{K}=M$. paniculata (leaves), $\mathrm{DA}=P$. niruri (whole plant) and $\mathrm{MK}=O$. stamineus (leaves). Orlistat served as a control and the final concentration was set at $10 \mu \mathrm{g} / \mathrm{ml}$.

The plant extracts with medium inhibition are known as $P$. acidus (leaves, C); G. atroviridis (leaves, AG); M. citrifolia (leaves, M); S. polyanthum (leaves, S); M. charantia (fruits, P); P. macrocarpa (leaves, MD) and P. betle L. (leaves, S). Meanwhile, the 13 plant extracts with low inhibition are known as $A$. galangal (rhizomes, L); Z. cassumunar (leaves, BL); G. procumbens (red) (leaves, SM); $G$. procumbens (green) (leaves, SH); C. nardus (leaves, SWD); C. nardus (shoots, SWI); C. papaya (leaves, B); K. galangal (leaves, CK); $T$. indica (leaves, AJ); H. sabdariffa (fruits, R); C. aeruginosa Roxb. (rhizomes, T); and G. atroviridis (fruits, AK). Among all the extracts, A. paniculata (leaves, $\mathrm{H})$ ] showed no inhibition towards PPL.

Of these 24 methanolic crude extracts, 17 were prepared from leaves, three from fruits, two from rhizomes and one each from the whole plant and shoots. Majority of extracts were prepared from the leaves, which primarily due to the significant usage of the leaves compared to other parts of the plant. The same factor contributes to the selection of rhizomes from A. galangal and C. aeruginosa Roxb., in which the rhizomes play a significant role in traditional medication or cooking purposes. ${ }^{25,26}$ Other factors, such as the moisture content of certain parts, especially the fruits, restricted the selection for this study since the drying process was carried out at ambient temperature $\left(25-30^{\circ} \mathrm{C}\right)$, which could promote the growth of fungi. M. charantia is a common vegetable consumed by locals. The fruit is believed to be the most significant part to treat obesity or other illnesses associated with obesity. ${ }^{27,28}$ Besides, the moisture content of $M$. charantia was low and easy to handle during drying process, while dried fruits from G. atroviridis and H. sabdariffa were easily obtained from a local market. C. nardus is a common ornamental in which the oil from leaves and shoots is frequently added in the slimming lotion. Both leaves and shoots are also added in the preparation of hot bath for confinement purpose. ${ }^{29}$ Thus, crude extract of both leaves and shoots from $C$. nardus was chosen for lipase-inhibitory activity screening. In this study, P. niruri was prepared using the whole plant. This is due to the fact that $P$. niruri is commonly small herb and was employed in this manner in folk medicine.

The findings from $\mathrm{IC}_{50}$ value showed that the four most active plant extracts markedly inhibited the pancreatic lipase activity in a dose-dependent manner (Figure 2). P. niruri extract was the most effective pancreatic lipase inhibitor followed by $O$. stamineus, $M$. paniculata and A. bilimbi with the $\mathrm{IC}_{50}$ value of $27.7<34.7<41.5<$ $55.2 \mu \mathrm{g} / \mathrm{ml}$, respectively. However, all extracts were less potent than orlistat (control) in inhibiting pancreatic lipase. Orlistat gave an $\mathrm{IC}_{50}$ value of $1.7 \mu \mathrm{g} / \mathrm{ml}$, which was about 17 times stronger than $P$. niruri crude extract. Adisakwattana et al.,$^{30}$ also reported the same when screened for lipase inhibition from selected edible plant crude extracts in Thailand.

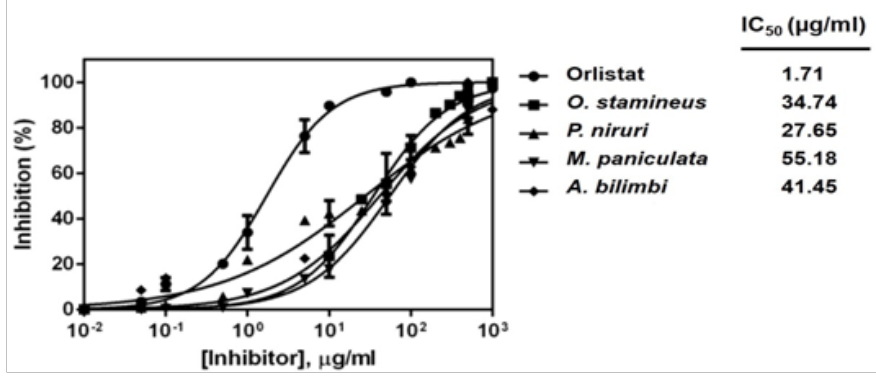

Figure $\mathbf{2} \mathrm{IC}_{50}$ determination of selected plant extracts.

The $\mathrm{IC}_{50}$ value in descending order of $P$. niruri $<$ O. stamineus $<M$. paniculata $<$ A. bilimbi $; 27.7<34.7<41.5<55.2 \mu \mathrm{g} / \mathrm{ml}$, respectively. The selection was based on the plant extracts producing the highest lipaseinhibitory activity ( $>70 \%$ inhibition). Orlistat served as a control. Data were presented as the mean standard deviation $(n \geq 3)$.

At this point, it may be speculated that there was a presence of both active and non-active compounds in the crude extract. In the event of crude extract application, a synergistic or antagonistic action may expedite or retard the efficacy of the main compound responsible of therapeutic action. ${ }^{31}$ The efficacy of the active compound may be affected if antagonistic action occurs. Iswantini et al., ${ }^{32}$ studied the pancreatic lipase inhibition of combined extracts of Z. cassumunar, G. ulmifolia, and M. paniculata. The results displayed that individual extract showed inhibition towards lipase, but in a very low percentage. However, when extracts of $Z$. cassumunar, G. ulmifolia, and M. paniculata of water extraction were combined with the ratio of $75: 45: 100 \mathrm{ppm}$, the combined extracts became antagonistic towards one another, resulting in no inhibition at all. Hence, the active 
compound should be isolated in pure form, so that the comparison between the $\mathrm{IC}_{50}$ value of lipase inhibition and the inhibition mode of the chosen crude and pure extract can be understood clearly. Among the four most active plant species, O. stamineus and M. paniculata have been investigated previously for their lipase-inhibitory activity. ${ }^{29,31}$ Iswantini et al., ${ }^{32}$ reported that $100 \mathrm{ppm}$ of $M$. paniculata aqueous extract inhibited pancreatic lipase by $25.66 \%$ which was strikingly lower than the findings in this study (75.6\%) (Table 2). This might be due to different methods and solvent used for extraction. Besides, the authors used triolein, a substrate of longer chain-length to determine the pancreatic lipase-inhibitory activity in their study.

Table 2 PPL inhibition result of 24 methanolic plants extracts

\begin{tabular}{|c|c|c|c|c|c|c|}
\hline Scientific name & Family & Part used & Inhibition (\%) A & $I_{50}(\mu g / M I) B$ & Yield (\%) D & Abbreviation \\
\hline Andrographis paniculata & Acanthaceae & Leaf & $\mathrm{n}$ & nd & 16.1 & $\mathrm{H}$ \\
\hline Gynura procumbens & Asteraceae & Leaf & $32.5+3.2$ & nd & 5.9 & $\mathrm{SH}$ \\
\hline Gynura bicolour & Asteraceae & Leaf & $14.6+1.9$ & nd & 7.1 & SM \\
\hline Carica papaya & Caricaceae & Leaf & $20.5+5.1$ & nd & 11.9 & B \\
\hline Garcinia atroviridis & Clusiaceae & Fruit & $32.1+2.7$ & nd & 8.7 & AK \\
\hline Garcinia atroviridis & Clusiaceae & Leaf & $34.6+1.0$ & nd & 5.5 & AG \\
\hline Momordica charantia & Cucurbitaceae & Fruit & $41.2+4.4$ & nd & 12.6 & $P$ \\
\hline Tamarindus indica & Fabaceae & Leaf & $28.1+2.5$ & nd & 9.5 & AJ \\
\hline Orthosiphon stamineus Benth & Lamiaceae & Leaf & $95.3+3.1$ & 34.7 & 9.3 & MK \\
\hline Hibiscus sabdariffa & Malvaceae & Fruit & $29.6+0.2$ & nd & 7.7 & $\mathrm{R}$ \\
\hline Syzygium polyanthum & Myrtaceae & Leaf & $38.2+6.5$ & nd & 11.2 & $\mathrm{~S}$ \\
\hline Averrhoa bilimbi & Oxalidaceae & Leaf & $73.9+2.0$ & 55.2 & 6.5 & BB \\
\hline Phyllanthus acidus & Phyllanthaceae & Leaf & $33.9+4.4$ & nd & 5.9 & $\mathrm{C}$ \\
\hline Phyllanthus niruri & Phyllanthaceae & Whole plant & $76.7+0.4$ & 27.7 & 19.2 & DA \\
\hline Piper betle $L$. & Piperaceae & Leaf & $50.6+1.8$ & nd & 12.3 & SR \\
\hline Cymbopogon nardus & Poaceae & Leaf & $28.3+2.2$ & nd & 8.8 & SWD \\
\hline Cymbopogon nardus & Poaceae & Shoot & $16.6+0.8$ & nd & 7.3 & SWI \\
\hline Morinda citrifolia & Rubiaceae & Leaf & $37.0+1.4$ & nd & 9.7 & M \\
\hline Murraya paniculata & Rutaceae & Leaf & $75.6+5.4$ & 41.5 & 11.5 & K \\
\hline Phaleria macrocarpa & Thymelaeaceae & Leaf & $45.2+1.4$ & nd & 19.2 & MD \\
\hline Kaempferia galangal & Zingiberaceae & Leaf & $26.9+2.7$ & nd & 7.9 & CK \\
\hline Zingiber cassumunar & Zingiberaceae & Leaf & $11.7+3.3$ & nd & 6.5 & $\mathrm{BL}$ \\
\hline Alpinia galangal & Zingiberaceae & Rhizome & $11.4+0.7$ & nd & 6.1 & $\mathrm{~L}$ \\
\hline Curcuma aeruginosa Roxb. & Zingiberaceae & Rhizome & $29.6+0.2$ & nd & 9.4 & $\mathrm{~T}$ \\
\hline Orlistat (Control) & & & $99.6+0.3 c$ & 1.7 & - & - \\
\hline
\end{tabular}

a. Percentage of inhibition represents the ability of extract to inhibit pancreatic lipase activity in the medium; concentration tested was $500 \mu g / m l$ in the assay except for $c$. Determined based on the average of three independent replications. The values were expressed as mea \pm standard deviation $(n=3)$.

b. $\mathrm{IC}_{50}$, concentration causing $50 \%$ inhibition; concentration tested were varied from $10^{-2}$ to $10^{3} \mu \mathrm{g} / \mathrm{ml}$ in the assay.

c. Concentration tested in the assay was $10 \mu \mathrm{g} / \mathrm{ml}$.

d. Extraction yield of the crude extract in percentage.

$\mathrm{N}$, no inhibition; nd, not determine 
The results obtained from the 24 methanolic plant extracts are summarized in Table 2, including the extraction yield of all extracts. The extraction yield for all plants varied, ranging from 5.9 to $19.2 \%$. One of the reasons was due to the physiological characteristics or different features (traits) of the plants themselves. ${ }^{33}$ The way the plants were processed, for example; squeezing, chopping or grinding could significantly affect the yield of extract obtained, due to the density of their tissues. Grinding the plant samples into powder may provide a greater surface area and improve the extraction yield. ${ }^{34}$ Other than that, extraction yield can be maximized by applying different solvents or manipulating different types of extraction, duration of extraction, and the washing cycle of extraction. ${ }^{35,36}$

In this screening study all plants, despite the different parts chosen, were extracted using $80 \%$ methanol. This is because alcohol has been proven to degrade cell walls and seeds more efficiently than water, causing more polyphenols to be released from the cells. The application of more alcohol in the solvent could reduce degradation of polyphenols by enzyme polyphenol oxidase. In addition, since almost all of the identified constituents from plants are aromatic or saturated organic compounds, the most appropriate method of choice are often obtained through ethanol or methanol extraction. ${ }^{37}$

Several papers have reported $O$. stamineus to be a potential anti-obesity agent. Adisakwattana et al., ${ }^{30}$ stated that $O$. stamineus crude extract showed strong bile acid binding activity, in which it binds glycodeoxycholic acid to a degree of $53 \%$. Bile acid binding ability was considered as a potential way to treat hyperlipidemia. ${ }^{37}$ It has been hypothesized as a possible mechanism of lowering plasma cholesterol level. As a result, greater amount of cholesterol is converted to bile acids to maintain a steady level in the circulation. ${ }^{38}$ Sriplang et al., ${ }^{39}$ suggested that $O$. stamineus aqueous extract might be useful in the control of diabetes, one of the obesity-associated risk factor. According to their findings, $O$. stamineus extract markedly reduced hyperglycemia in streptozotocin (STZ)-induced diabetic rats, decreased plasma triglyceride and increased plasma high-density lipoprotein (HDL)-cholesterol concentrations. Yuliana ${ }^{40}$ stated that O. stamineus methanolic extract has an appetite suppression effect, another mechanism of anti-obesity drug, works by reducing the desire to eat. However, no active compound responsible for the anti-obesity or anti-lipase property of $O$. stamineus and $M$. paniculata has been reported until now.

P. niruri and A. bilimbi have never been reported to possess antilipase activity so far. $P$. niruri is popular plant in folk medicine. Whole plant, fresh leaves and fruits are used in the treatment of various diseases, such as dysentery, influenza, vaginitis, tumors, diabetes, diuretics, jaundice, kidney stone, dyspepsia, anti-hepatotoxic, antihepatitis-B, anti-hyperglycemic and also as antiviral and antibacterial agent. ${ }^{41}$ It holds a reputable position in both Ayurvedic and Unani systems of medicine. Although no report on P. niruri having antilipase activity, a few reports indirectly stated the ability of this plant as anti-obesity agent. The anti-diabetic action of $P$. niruri extract has been studied by many researchers. ${ }^{42-45}$ Okoli et al. ${ }^{44}$ reported the methanolic extract of aerial parts of $P$. niruri showed significant blood glucose lowering and glycemic control in diabetes. Khanna et al., ${ }^{46}$ reported on the effect of $P$. niruri on lipid and lipoprotein metabolism in triton-induced and cholesterol-fed hyperlipemia. According to the findings, $P$. niruri possessed lipid lowering action. Inhibition was mediated through hepatic cholesterol biosynthesis. This may support its role as a hepatoprotective agent.

A. bilimbi is medicinally used as a folk remedy for many symptoms. Various parts of A bilimbi such as the leaves, bark, flowers, fruits, seeds, roots or the whole plant have been applied for medicinal purposes. The leaves are applied as a paste or poultice on itches, swellings of mumps and rheumatism, and on skin eruptions. The leaves and fruit extracts have been reported to be an effective antibacterial agent against Escherichia coli, Staphylococcus aureus, and Salmonella enteritidis. ${ }^{47}$ A. bilimbi was also reported having anti-diabetic and anti-hyperlipidaemic action, which is one of the characteristic of anti-obesity agent. Pushparaj et al., ${ }^{48}$ examined the hypoglycemic activity of ethanolic extract of $A$. bilimbi leaves in STZ-diabetic rats. According to their findings, they concluded that, $A$. bilimbi ethanolic leaves extract significantly lowered blood glucose by $50 \%$, thus, has good hypoglycemic activity in STZ-diabetic rats. Ambili et al., ${ }^{49}$ studied the anti-hyperlipidaemic properties of $A$. bilimbi fruit using triton-induced hypercholesterolemia in rats as a model. The fruit $(125 \mathrm{mg} / \mathrm{kg})$ and its water extract $(50 \mathrm{mg} / \mathrm{kg})$ were found to be effective in lowering lipids in the high-fat diet fed rats. Hence, they concluded this fruit can be used as a dietary ingredient to prevent as well as to treat hyperlipidemia.

All selected plants showed inhibition towards pancreatic lipase except for A. paniculata. Plants with high activity may be regarded as a useful source of anti-obesity agents. Conversely, plants with medium to low inhibition did not seem to play a significant role as potential anti-lipase agent and can be regarded as poor inhibitors. Traditionally, A. paniculata was used to treat high blood pressure, jaundice, diabetes, fever, skin problems, flu, respiratory disease, and act as anti-venom against snakebite in East and Southeast Asia. ${ }^{50-53}$ As the prevalence of obesity and diabetes is common in our society, research on plants with anti-lipase, anti-diabetic, and anti-hyperlipidemic action has great value in modern therapeutics. The facts show that all of the four most active plant extracts, which are $P$. niruri, O. stamineus, $M$. paniculata and A. bilimbi, can be considered potent herbs with antiobesity properties for future research, as evidenced by the findings.

\section{Inhibition mode}

The inhibition mode of the four most active plant extracts has been visualized using graphical representation of the MichaelisMenten equation, Hanes-Woolf plot; [S]/v versus [S], as shown in Figure 3. The inhibition mode was plotted from the enzyme assay data containing increasing concentrations of pNPB substrate $(0.25$, $0.5,1.0,2.0,4.0$ and $6.0 \mathrm{mM})$ with the absence and presence of difference concentration of extracts $(10$ and $50 \mu \mathrm{g} / \mathrm{ml})$. It is important to calculate $\mathrm{Km}$ (substrate concentration at which the reaction rate is half-maximum or half of Vmax or also known as MichaelisMenten constant) and $\mathrm{V}_{\max }$ (maximum rate at saturating substrate concentrations) to understand the enzyme characteristics.

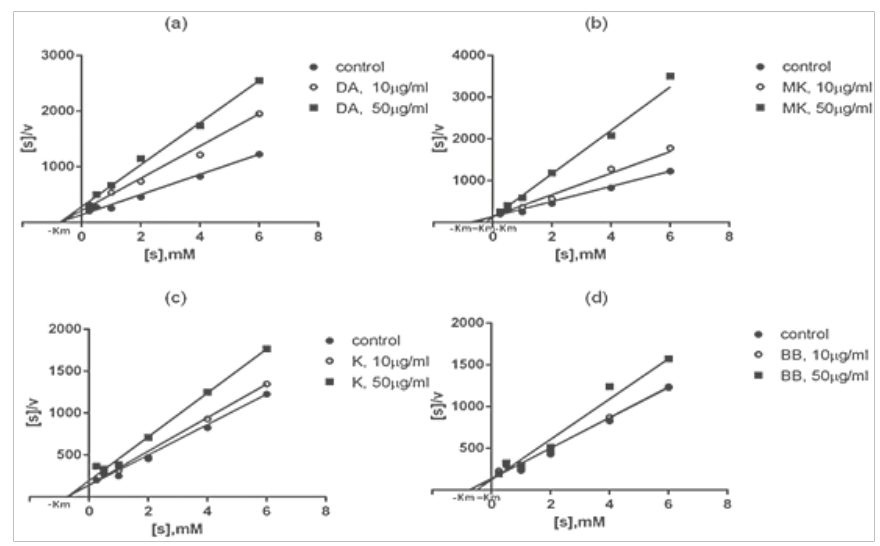

Figure 3 Inhibition mode determination. 
Hanes-Woolf plot; [S]/v versus [S] of kinetic analysis for PPL at two different concentrations of (a) P. niruri extract (Abbreviated as DA), (b) O. stamineus extract (Abbreviated as MK), (c) M. paniculata extract (Abbreviated as $\mathrm{K}$ ) and (d) A. bilimbi extract (Abbreviated as $\mathrm{BB})$. Data were presented as the mean standard deviation $(n \geq 3)$.

The enzyme kinetics result showed that $P$. niruri and $M$. paniculata extracts exerted inhibitory effect on pancreatic lipase in a noncompetitive manner. As depicted from the graph, when the extracts' concentrations were increased, the values for the y-intercept in the equation for each curve increased, whereas the $\mathrm{x}$-intercepts remained at a fixed point showing that these inhibitors do not affect $\mathrm{Km}$ but the Vmax decreased. Km value for PPL was $0.76 \mathrm{mM}$ and $\mathrm{V}_{\max }$ was $0.0057 \mathrm{mM} / \mathrm{min}$. Kinetic study in the presence of $P$. niruri and M. paniculata extracts showed reduction of $V \max$ to 0.0027 and $0.0036 \mathrm{mM} / \mathrm{min}$, respectively. Therefore, it was concluded that both $P$. niruri and $M$. paniculata extracts inhibited pancreatic lipase by binding with the free enzyme or the enzyme-substrate complex.

$O$. stamineus and $A$. bilimbi showed uncompetitive inhibition towards pancreatic lipase activity. The uncompetitive inhibition lines intersected on the $y$-axis whereas the value for the $x$-intercept in the equation for each curve increased; illustrating that such inhibitors affected both Vmax and $\mathrm{Km}$. Km value for PPL was $0.76 \mathrm{mM}$ and Vmax was $0.0057 \mathrm{mM} / \mathrm{min}$. In the presence of $O$. stamineus and $A$. bilimbi extracts, $\mathrm{Km}$ was reduced to 0.23 and $0.51 \mathrm{mM}$, respectively, while $\mathrm{V}_{\max }$ was reduced to 0.0019 and $0.004 \mathrm{mM} / \mathrm{min}$. Therefore, both $O$. stamineus and $A$. bilimbi extracts inhibited pancreatic lipase by binding with only the enzyme-substrate complex. This is due to the fact that uncompetitive inhibition takes place when an enzyme inhibitor binds only to the complex formed between the enzyme and the substrate. This shows that the substrate binding could cause a conformational change to take place in the enzyme that enables the inhibitor to bind to the enzyme-substrate complex. ${ }^{54}$

These findings may present a preliminary result of the pancreatic lipase inhibition mode of these four potential plants. However, it should be kept inmind that the extracts tested are in crude form. The presence of both active and non-active compounds in the crude extract may create synergistic action. Furthermore, there is a possibility that these extracts are having more than one lipase inhibitor. Thus, it might affect the results. Accordingly, it is essential to check the inhibition mode of the pure compound later to validate the verdicts. However, a few papers have reported the same kinetic study in the presence of crude extracts. ${ }^{55-57}$

\section{Antioxidant activity of $O$. stamineus and $P$. niruri extracts}

Antioxidants may be defined as compounds that inhibit or delay the oxidation of other molecules by inhibiting the initiation or propagation of oxidizing chain reactions. ${ }^{58}$ Antioxidants can also protect the human body from free radicals and reactive oxygen species effects. They retard the progress of many chronic diseases as well as lipid peroxidation. ${ }^{59}$ Natural antioxidants tend to be safer and are known to exhibit a wide range of biological effects including antilipase, antibacterial, antiviral, anti-inflammatory, anti-allergic, antithrombotic and vasodilatory activities. ${ }^{59,60}$

The potential of $O$. stamineus and P. niruri extracts as free radical scavenger was analysed using DPPH scavenging assay. This nonenzymatic assay is widely accepted as a tool to assess free radical scavenging activity of antioxidant for its advantage of economical and ease ${ }^{61}$ DPPH is a stable nitrogen-centered organic radical with a characteristic absorption within $515-528 \mathrm{~nm} .^{62}$ This easy and convenient assay is based on the reduction of the alcoholic DPPH solution in the presence of antioxidant. Antioxidants interrupt free radical chain oxidation by donating hydrogen from hydroxyl groups to form a stable end product, diphenylpicrylhydrazine (DPPH), which does not initiate or propagate further oxidation of lipids. This causes the purple-coloured DPPH to lose its chromophore and turn it into a yellowish product ( $\alpha, \alpha$-diphenyl- $\beta$-picryl hydrazine) ${ }^{63-65}$

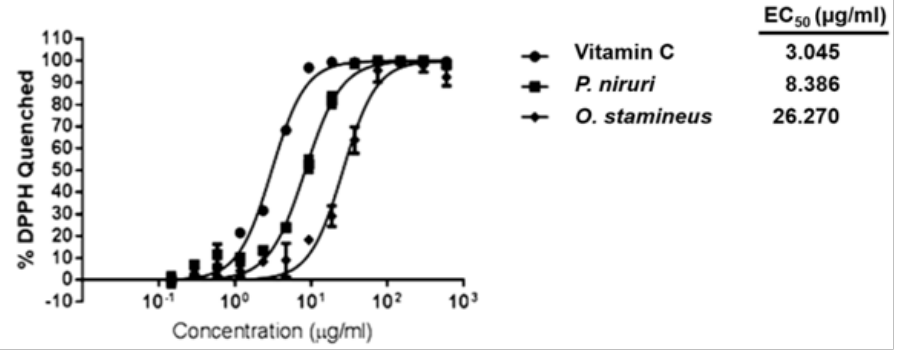

Figure 4 Antioxidant activities of $O$. stamineus and $P$. niruri extracts at different concentration.

A transform of dose-response curve of DPPH radicals scavenging activities of the $P$. niruri and $O$. stamineus crude extracts was presented in Figure 4. The transform of dose-response curve was constructed to determine the $\mathrm{EC}_{50}$ value of both extracts. $\mathrm{EC}_{50}$ value refers to the effective concentration of antioxidant agent that is required to scavenge $50 \%$ of the radicals under experimental condition. The lowest $\mathrm{EC}_{50}$ value indicates the strongest ability of sample to act as DPPH radical scavenger. It was observed that the DPPH radicalscavenging activity increased as the concentration of the extract increased. The scavenging activity of $O$. stamineus and $P$. niruri extracts toward DPPH radicals increased from 0.2 to $500 \mu \mathrm{g} / \mathrm{ml}$ and was $91.8 \%$ and $93.6 \%$ at a concentration of $500 \mu \mathrm{g} / \mathrm{ml}$, respectively.

As shown in Figure 4, P. niruri extract has reached maximum plateau within the range of concentration. $P$. niruri extract showed greater ability to inhibit DPPH radical than $O$. stamineus extract with recorded $\mathrm{EC}_{50}$ value of $8.386 \mu \mathrm{g} / \mathrm{ml}$. Although $O$. stamineus extract displayed lower antioxidant activity when compare with $P$. niruri extract, with an $\mathrm{EC}_{50}$ value of $26.27 \mu \mathrm{g} / \mathrm{ml}, O$. stamineus extract may be classified as a good antioxidant agent. Ascorbic acid (Vitamin C) served as the positive control with an $\mathrm{EC}_{50}$ of $3.045 \mu \mathrm{g} / \mathrm{ml}$.

The antioxidant activities were defined as inhibition percentage of DPPH in DPPH assay. Vitamin C served as the positive control. Data were presented as the mean standard deviation $(n=3)$.

\section{TPC and TFC of $O$. stamineus and $P$. niruri extracts}

Phenolic acids and flavonoids are secondary metabolites widely distributed in the plant kingdom. Plant phenolics and flavonoids are very effective free-radical scavengers and their antioxidant activities are well documented. ${ }^{66}$ Hence, plants which contain high levels of phenolics and flavonoids are indeed a good source of antioxidants and therefore it is important to quantify the total phenolics and total flavonoids in plant extracts as they might have some beneficial effects on health..$^{67,68}$

The amount of phenolic compounds in P. niruri and O. stamineus extracts were determined using the Folin-Ciocalteau colourimetric method. By manipulating the regression equation of gallic acid 
calibration curve $(y=2.640 x+0.1759, r 2=0.9878)$, the TPC of each extract was calculated and expressed as gallic acid equivalent (GAE). TPC of $O$. stamineus extract was $103+0.08 \mathrm{mg} \mathrm{GAE} / \mathrm{g}$ dry extract while $P$. niruri extract displayed dramatically higher TPC with $431+0.01 \mathrm{mg}$ GAE/g dry extract (Table 3). This indicates that $P$. niruri has good potential as a source for natural antioxidant to prevent free radical oxidative damage. The antioxidant activity of phenolic compounds is mainly attributed to their redox properties, which allow them to act as reducing agents, hydrogen donors and quenchers of singlet oxygen.
In addition, they may also possess metal chelation properties.$^{69}$ Levels of flavonoid compounds in $O$. stamineus and P. niruri extracts were determined using the aluminium chloride colourimetric assay. By manipulating the regression equation of quercetin calibration curve $(y=0.00669 x-0.004667, r 2=0.9977)$, the TFC of each extract was calculated and expressed as quercetin equivalent (QE). The TFC of $O$. stamineus extract was slightly higher than $P$. niruri extract with $21.6 \pm 0.03$ and $14.8 \pm 0.07 \mathrm{mg} \mathrm{QE} / \mathrm{g}$ dry extract, respectively (Table 3 ).

Table 3 Summary of TPC,TFC, anti-lipase activity and antioxidant activity of P. niruri and $O$. stamineus extract

\begin{tabular}{lllll}
\hline & $\begin{array}{l}\text { Total Phenolic Content (Mg } \\
\text { GAE/G Dry Extract) }\end{array}$ & $\begin{array}{l}\text { Total Flavonoid Content (Mg } \\
\text { QE/G Dry Extract) }\end{array}$ & $\begin{array}{l}\text { Anti-Lipase Activity [I } \\
\left.\mathbf{C}_{50}(\mu \mathrm{g} / \mathrm{MI})\right]\end{array}$ & $\begin{array}{l}\text { Antioxidant Activity } \\
{\left[\mathrm{E} \mathrm{C} \mathbf{C}_{50}(\mu \mathrm{\mu g} / \mathrm{MI})\right]}\end{array}$ \\
\hline P. niruri & $431.0 \pm 0.01$ & $14.8 \pm 0.07$ & 28.13 & 8.39 \\
O. stamineus & $103.0 \pm 0.08$ & $21.6 \pm 0.03$ & 44.05 & 26.27 \\
\hline
\end{tabular}

The values were expressed as mean \pm standard deviation $(n=3)$

O. stamineus contains several chemically active constituents, but one of the most important classes of compounds is the phenolic group. ${ }^{70}$ A study of $50 \%$ ethanol extract of $O$. stamineus leaves for its anti-tumor potential showed an ability to inhibit colon tumor in mice could be attributed mainly to its antioxidant-rich polyphenolic contents, the caffeic acid derivatives, polymethoxylated flavonoids and terpenes; particularly rosmarinic acid, eupatorin, sinensetin, 3'-hydroxy-5,6,7,4'-tetramethoxyflavone, and betulinic acid. ${ }^{71}$ The authors found that flavonoids and phenolics in the extract possessed very promising antiangiogenic properties. Akowuah et al., ${ }^{66}$ studied the phytochemicals content of $O$. stamineus collected from different locations in Malaysia. They reported the samples from various locations showed a remarkable degree of variation of their antioxidant activity. Besides, the TPC of the methanol extracts varied from $6.69 \mathrm{mg}$ caffeic acid/g dry weight in the sample from Pasir Puteh (Kelantan) to $10.20 \mathrm{mg}$ caffeic acid/g dry weight in the sample from Parit (Perak). Variations in the free-radical activity may be due to agronomic practices and environmental conditions which at once could affect both soil fertility levels and phytochemicals content. ${ }^{66}$

Extensive research on $P$. niruri active constituents and their pharmacological activities was begun in the mid-1960s. Several classes of chemicals have been found in P. niruri, including lignans, alkaloids, benzenoids, coumarins, lipid, sterol, tannin, terpenes, saponins and flavonoids. ${ }^{72}$ A few flavonoid from $P$. niruri that have been reported so far include quercetin, rutin, astragalin, quercitrin, isoquercitrin, kaempferol-4'-rhamnopyranoside, fisetin-4-oglucoside and nirurin. ${ }^{73,74}$ Harish \& Shivanandappa ${ }^{72}$ investigated the antioxidant activity and hepatoprotective potential of $P$. niruri. Their findings also revealed the high potency of the crude extracts of $P$. niruri in free radical scavenging, inhibition of reactive oxygen species and lipid peroxidation in both in vivo and in vitro. However, they stated that there was no correlation between antioxidant activity and phenolics content of the $P$. niruri extracts, which suggests that besides phenolics, other chemical constituents may contribute to antioxidant activity. This, at once suggests that although individual phenolics may have considerable antioxidant potential, there could be synergistic or antagonistic interactions between phenolic and non-phenolic compounds. Khanna et al., ${ }^{46}$ studied the lipid-lowering activity of $P$. niruri in triton and cholesterol fed hyperlipidemic rats, however, they did not stated the active phytochemical constituent that responsible for the lipid lowering activity. Up to now, there is still a lack of information on the relationship between anti-lipase activity and their phenolic or flavonoid compounds on a large scale to reveal whether their relationship is positive or negative. Overall, the results suggest that $P$. niruri \& $O$. stamineus may be beneficial for obesity treatment via pancreatic lipase inhibition action.

\section{Acknowledgements}

This research project was supported by an Exploratory Research Grant Scheme from theministry of Higher Education Malaysia (Research University grant no. ERGS/1-2012/5527079).

\section{Conflict of interest}

The author declares no conflict of interest.

\section{References}

1. Wu X, He W, Zhang H, et al. Acteoside: a lipase inhibitor from the Chinese tea Ligustrum purpurascens kudingcha. Food Chem. 2014;142:306-310.

2. Eom SH, Lee MS, Lee EW, et al. Pancreatic Lipase Inhibitory Activity of Phlorotannins Isolated from Eisenia bicyclis. Phytotherapy Research. 2013;27(1):148-151.

3. Sirinamarattana A, Bavovada R, Pengsuparp T, et al. Pancreatic Lipase Inhibitory Activity of Thai Medicinal Plants. Journal of Pharmacy Research. 2010;3(10):2402-2403.

4. Han LK, Zheng YN, Yoshikawa M, et al. Anti-obesity effects of chikusetsu saponins isolated from Panax japonicus rhizomes. $B M C$ Complementary and Alternative Medicine. 2005;5:9.

5. Kishino E, Ito T, Fujita K, et al. A Mixture of the Salacia reticulata (Kotala himbutu) Aqueous Extract and Cyclodextrin Reduces the Accumulation of Visceral Fat Mass in Mice and Rats with High-Fat Diet-Induced Obesity. J Nutr. 2006;136(2):433-439.

6. Lei F, Zhang XN, Wang W, et al. Evidence of anti-obesity effects of the pomegranate leaf extract in high-fat diet induced obese mice. Int J Obes. 2007;31(6):1023-1029.

7. Ono Y, Hattori E, Fukaya Y, et al. Anti-obesity effect of Nelumbo nucifera leaves extract in mice and rats. J Ethnopharmacol. 2006;106(2):238-244.

8. Sharma N, Sharma VK, Seo SY. Screening of some medicinal plants for anti-lipase activity. J Ethnopharmacol. 2005;97(3):453-456.

9. Zheng CD, Duan YQ, Gao JM, et al. Screening for Anti-lipase Properties of 37 Traditional Chinese Medicinal Herbs. J Chin Med Assoc. 2010;73(6):319-324. 
10. Dechakhamphu A, Wongchum N. Screening for anti-pancreatic lipase properties of 28 traditional Thai medicinal herbs. Asian Pacific Journal of Tropical Biomedicine. 2015;5(12):1042-1045.

11. Mukherjee M. Human digestive and metabolic lipases-a brief review. Journal of Molecular Catalysis B: Enzymatic. 2003;22(5-6):369-376.

12. Thomson ABR, De Pover A, Keelan M, et al. Lipases Part B: Enzyme Characterization and Utilization. 1st ed. Methods in Enzymology. Netherlands: Elsevier; 1997. 563 p

13. Shi Y, Burn P. Lipid metabolic enzymes: emerging drug targets for the treatment of obesity. Nat Rev Drug Disc. 2004;3(8):695-710.

14. WHO. Traditional Medicine Strategy: 2014-2023. 2013. 76 p.

15. Lehner R, Verger R. Purification and characterization of a porcine liver microsomal triacylglycerol hydrolase. Biochemistry. 1997;36(7):18611868.

16. Lewis DR. Direct Measurement of Lipase Inhibition by Orlistat Using a Dissolution Linked In Vitro Assay. Clinical Pharmacology \& Biopharmaceutics. 2012;1(3):1-3.

17. Zakaria ZA, Balan T, Suppaiah V, et al. Mechanism(s) of action involved in the gastroprotective activity of Muntingia calabura.JEthnopharmacol. 2014;151(3):1184-1193

18. Abdullah MI. Physicochemical profiling and detection of phenolic constituents with antioxidant and antibacterial activities of Myristica fragrans Houtt. Malaysia: Universiti Sains Malaysia; 2009. p. 1-24.

19. Hakiman M. Total antioxidant, polyphenol, phenolic acid, and flavonoid content in Ficus deltoidea varieties. Journal of Medicinal Plants Research. 2012;6(33):4776-4784.

20. Park YS, Jung ST, Kang SG, et al. Antioxidants and proteins in ethylenetreated kiwifruits. Food Chemistry. 2008;107(2):640-648.

21. Saeed N, Khan MR, Shabbir M. Antioxidant activity, total phenolic and total flavonoid contents of whole plant extracts Torilis leptophylla $L$. BMC Complement Altern Med. 2012;12(1):221.

22. Ado MA. Screening of Malaysian Medicinal/Herbs and Aquatic Plants for Pancreatic Lipase Inhibitory Activities and Identification of Active Constituent. Malaysia: Universiti Putra Malaysia; 2010

23. Bustanji Y, Issa A, Mohammad M, et al. Inhibition of hormone sensitive lipase and pancreatic lipase by Rosmarinus officinalis extract and selected phenolic constituents. Journal of Medicinal Plants Research 2010;4(21):2235-2242.

24. Lowe ME, Rosenblum JL, Strauss AW. Cloning and characterization of human pancreatic lipase cDNA. Journal of Biological Chemistry. 1989;264(33):20042-20048

25. Acuthan CR, Padikkala J. Hypolipidemic effect of Alpinia galanga (Rasna) and Kaempferia galanga (Kachoori). Indian J Clin Biochem. 1997;12(1):55-58.

26. Pujiyanto S, Lestari Y, Suwanto A, et al. Alpha-glucosidase inhibitor activity and characterization of endophytic Actinomycetes isolated from some Indonesian diabetic medicinal plants. International Journal of Pharmacy and Pharmaceutical Sciences. 2012;4:327-333.

27. Gooda Sahib N, Abdul Hamid A, Saari N, et al. Anti-Pancreatic Lipase and Antioxidant Activity of Selected Tropical Herbs. International Journal of Food Properties. 2012;15(3):569-578.

28. Mohamed S. Functional foods against metabolic syndrome (obesity, diabetes, hypertension and dyslipidemia) and cardiovasular disease Trends in Food Science \& Technology. 2014;35(2):114-128.

29. Anonymous. Petua Wanita: Untuk Wanita Dalam Pantang. 2015.

30. Adisakwattana S, Intrawangso J, Hemrid A, et al. Extracts of Edible Plants Inhibit Pancreatic Lipase, Cholesterol Esterase and Cholesterol Micellization, and Bind Bile Acids. Food Technology and Biotechnology. 2012;50(1):11-16.
31. Gertsch J. Botanical Drugs, Synergy, and Network Pharmacology: Forth and Back to Intelligent Mixtures. Planta Med. 2011;77(11):1086-1098.

32. Iswantini D, Silitonga RF, Martatilofa E, et al. Zingiber cassumunar, Guazuma ulmifolia, and Murraya paniculata Extracts as Antiobesity:In Vitro Inhibitory Effect on Pancreatic Lipase Activity. Hayati Journal of Biosciences. 2011;18(1):6-10.

33. Ahmed IM, Cao F, Zhang M, et al. Difference in Yield and Physiological Features in Response to Drought and Salinity Combined Stress during Anthesis in Tibetan Wild and Cultivated Barleys. PLoS One. 2013;8(10):1-14

34. Redfern J, Kinninmonth M, Verran J, et al. Using Soxhlet Ethanol Extraction to Produce and Test Plant Material (Essential Oils) for Their Antimicrobial Properties. J Microbiol Biol Edu. 2014;15(1):45-46.

35. Ahmad A, Alkarkhi AFM, Hena S, et al. Extraction, Separation and Identification of Chemical Ingredients of Elephantopus scaber L. Using Factorial Design of Experiment. International Journal of Chemistry. 2009;1(1):36-49.

36. Mac Tavish, Hazel Smith. Factors affecting yield and composition of floral extract from Boronia megastigma Nees. Australia; University of Tasmania; 1995

37. Tiwari P, Kumar B, Mandeep K, et al. Phytochemical screening and Extraction: A Review. Internationale Pharmaceutica Sciencia. 2011;1(1):98-106.

38. Staels B, Handelsman Y, Fonseca V. Bile Acid Sequestrants for Lipid and Glucose Control. Curr Diab Rep. 2010;10(1):70-77.

39. Insull WJ. Clinical utility of bile acid sequestrants in the treatment of dyslipidemia: a scientific review. South Med J. 2006;99(3):257-273.

40. Sriplang K, Adisakwattana S, Rungsipipat A, et al. Effects of Orthosiphon stamineus aqueous extract on plasma glucose concentration and lipid profile in normal and streptozotocin-induced diabetic rats. Journal of Ethnopharmacology. 2007;109(3):510-514.

41. Yuliana ND, Rosa D, Korthout HV. Screening of anti-obesity compounds from Orthosiphon stamineus with the CB1 assay. Obesity Facts. 2009;2:250.

42. Paithankar VV, Raut KS, Charde RM, et al. Phyllanthus niruri:A magic Herb. Research in Pharmacy. 2011;1(4):1-9.

43. Bavarva JH, Narasimhacharya AVRL. Comparative Antidiabetic, Hypolipidemic, and Antioxidant Properties of Phyllanthus niruri in Normal and Diabetic Rats. Pharmaceutical Biology. 2007;45(7):569574.

44. Narendra K, Swathi J, Sowjanya KM, et al. Phyllanthus niruri: A Review on its Ethno Botanical, Phytochemical and Pharmacological Profile. Journal of Pharmacy Research. 2012;5(9):4681-4691.

45. Okoli CO, Obidike IC, Ezike AC, et al. Studies on the possible mechanisms of antidiabetic activity of extract of aerial parts of Phyllanthus niruri. Pharm Bio. 2011;149(3):248-255.

46. Shetti AA, Sanakal RD, Kaliwal BB. Antidiabetic effect of ethanolic leaf extract of Phyllanthus amarus in alloxan induced diabetic mice. Asian Journal of Plant Science and Research. 2012;2(1):11-15.

47. Khanna AK, Rizvi F, Chander R. Lipid lowering activity of Phyllanthus niruri in hyperlipemic rats. J Ethnopharmacol. 2002;82(1):19-22.

48. Roy A, Rv G, Lakshmi T. Averrhoa bilimbi Linn - Nature's Drug Store-A Pharmacological Review Scientific classification. International Journal of Drug Development and Research. 2011;3(3):101-106.

49. Pushparaj PN, Tan BKH, Tan CH. The mechanism of hypoglycemic action of the semi-purified fractions of Averrhoa bilimbi in streptozotocindiabetic rats. Life Sci. 2001;70(5):535-547.

50. Ambili S, Subramoniam A, Nagarajan SN. Studies on the Antihyperlipidemic Properties of Averrhoa bilimbi Fruit in Rats. Planta Med. 2009;75(1):55-58. 
51. Bachok MF, Yusof BNM, Ismail A, et al. Effectiveness of traditiona Malaysian vegetables (ulam) in modulating blood glucose levels. Asia Pac J of Clin Nutr. 2014;23(3):369-376.

52. Raina AP, Gupta V, Sivaraj N, et al. Andrographis paniculata (Burm. f.) Wall. ex Nees (kalmegh), a traditional hepatoprotective drug from India. Genetic Resources and Crop Evolution. 2013;60(3):1181-1189.

53. Valdiani A, Kadir MA, Tan SG, et al. Nain-e havandi Andrographis paniculata present yesterday, absent today:A plenary review on underutilized herb of Iran's pharmaceutical plants. Molecular Biology Reports. 2012;39(5):5409-5424.

54. Ong HC, Norzalina J. Malay herbal medicine in Gemencheh. Negri Sembilan, Malaysia. Fitoterapia. 1999;70(1):10-14.

55. Selvaraj G, Kaliamurthi S, Thirugnanasambandam R. Influence of Rhizophora apiculata Blume extracts on $\alpha$-glucosidase:Enzyme kinetics and molecular docking studies. Biocatalysis and Agricultural Biotechnology. 2015;4(4):653-660.

56. Gu Y, Hurst WJ, Stuart DA, et al. Inhibition of key digestive enzymes by cocoa extracts and procyanidins. J Agric Food Chem. 2011;59(10):53055311 .

57. Kim YM, Jeong YK, Wang MH, et al. Inhibitory effect of pine extract on $\alpha$-glucosidase activity and postprandial hyperglycemia. Nutrition. 2005;21(6):756-761.

58. Kotowaroo MI, Mahomoodally MF, Gurib Fakim A, et al. Screening of traditional antidiabetic medicinal plants of Mauritius for possible $\alpha-$ amylase inhibitory effects in vitro. Phytother Res. 2006;20(3):228-231.

59. Velioglu YS, Mazza G, Gao L, et al. Antioxidant Activity and Total Phenolics in Selected Fruits, Vegetables, and Grain Products. Journal of Agricultural and Food Chemistry. 1998;46(10):4113-4117.

60. Gülçin İ, Huyut Z, Elmastaş M, et al. Radical scavenging and antioxidan activity of tannic acid. Arabian Journal of Chemistry. 2010;3(1):43-53.

61. Agati G, Azzarello E, Pollastri S, et al. Flavonoids as antioxidants in plants: location and functional significance. Plant Science: An International Journal of Experimental Plant Biology. 2012;196:67-76.

62. Pan Y, Wang K, Huang S, et al. Antioxidant activity of microwaveassisted extract of longan (Dimocarpus longan Lour.) peel. Food Chemistry. 2008;106(3):1264-1270.

63. Sultana B, Anwar F, Przybylski R. Antioxidant activity of phenolic components present in barks of Azadirachta indica, Terminalia arjuna, Acacia nilotica, and Eugenia jambolana Lam. trees. Food Chemistry. 2007;104(3):1106-1114.
64. Carvalho BMA, Santos JDL, Xavier BM, et al. Snake Venom PLA 2 S Inhibitors Isolated from Brazilian Plants: Synthetic and Natural Molecules. BioMed Research International. 2013;2013:1-8.

65. Gulati V, Harding IH, Palombo EA. Enzyme inhibitory and antioxidant activities of traditional medicinal plants: potential application in the management of hyperglycemia. BMC Complementary and Alternative Medicine. 2012;12(77):1-9.

66. Soares JR, Dinis TC, Cunha AP, et al. Antioxidant activities of some extracts of Thymus zygis. Free Radical Research. 1997;26(5):469-478.

67. Akowuah GA, Zhari I, Norhayati I, et al. Radical Scavenging Activity of Methanol Leaf Extracts of Orthosiphon stamineus. Pharmaceutical Biology. 2005;42(8):629-635.

68. Gorinstein S, Zachwieja Z, Katrich E, et al. Comparison of the contents of the main antioxidant compounds and the antioxidant activity of white grapefruit and his new hybrid. Lebensmittel-Wissenschaft UndTechnologie. 2004;37(3):337-343.

69. Liyana Pathirana CM, Shahidi F. Antioxidant properties of commercial soft and hard winter wheats (Triticum aestivum L.) and their milling fractions. Journal of the Science of Food and Agriculture. $2006 ; 86(3): 477-485$

70. Akowuah GA, Zhari I, Norhayati I, et al. Sinensetin, eupatorin, 3'hydroxy-5, 6, 7, 4'-tetramethoxyflavone and rosmarinic acid contents and antioxidative effect of Orthosiphon stamineus from Malaysia. Food Chemistry. 2004;87(4):559-566.

71. Ahamed MBK, Aisha AFA, Nassar ZD, et al. Cat's Whiskers Tea (Orthosiphon Stamineus) Extract Inhibits Growth of Colon Tumor in Nude Mice and Angiogenesis in Endothelial Cells via Suppressing VEGFR Phosphorylation. Nutrition and Cancer. 2012;64(1):89-99.

72. Harish R, Shivanandappa T. Antioxidant activity and hepatoprotective potential of Phyllanthus niruri. Food Chemistry. 2006;95(2):180-185.

73. Calixto JB, Santos ARS, Filho VC, et al. A review of the plants of the genus Phyllanthus: their chemistry, pharmacology, and therapeutic potential. Med Res Rev. 1998;18(4):225-258.

74. Rajeshkumar NV, Joy KL, Kuttan G, et al. Antitumour and anticarcinogenic activity of Phyllanthus amarus extract. $J$ Ethnopharmacol. 2002;81(1):17-22. 